\title{
Entrance into teaching and need for support - narratives from diverse national and local contexts
}

\author{
Marit Ulvik $^{1 *}$, Ingrid Helleve ${ }^{2}$, Kari Smith ${ }^{3}$ \\ ${ }^{1}$ Institutt for pedagogikk, Universitetet i Bergen \\ ${ }^{2}$ Institutt for pedagogikk, Universitetet i Bergen \\ ${ }^{3}$ Institutt for lærerutdanning, Norges teknisk-naturvitenskapelige universitet (NTNU) \\ *Correspondence: marit.ulvik@uib.no
}

\begin{abstract}
The study investigates how a group of newly qualified teachers in diverse national and local contexts experience the entrance into teaching. The study is based on narratives from new teachers in Australia, England, and Norway. By listening to their stories, the aim is to develop the understanding of this particular phase in teachers' professional life and learn more about how to support NQTs. The findings suggest that there are more similarities than differences across the included nations concerning the entrance of the profession. When it comes to support the needs are similar, but the frameworks for support and mentoring are different. Implications from the study is that there are commonalities involved that make it possible to learn from each other when it comes to develop frameworks for support and mentoring and what contributes to professional development across national contexts.
\end{abstract}

Keywords: newly qualified teachers, induction, mentoring, professional development

\section{Sammendrag}

Denne studien undersøker hvordan en gruppe nye lærere i ulike nasjonale og lokale sammenhenger erfarer inngangen til læreryrket. Studien er basert på narrativer fra nye lærere i Australia, England og Norge. Ved å lytte til deres fortellinger, er målet å utvikle en forståelse for denne spesifikke fasen i læreres profesjonelle liv og å lære mer om hvordan nyutdannede kan støttes. Funnene indikerer at det på tvers av de aktuelle nasjonene er flere likheter enn forskjeller knyttet til inngangen til lærerprofesjonen. Når det gjelder støtte, er behovene mye de samme, men rammene rundt veiledning og annen støtte er forskjellige. Studien impliserer at det er likheter som gjør det mulig å lære av hverandre når det gjelder rammeverket for støtte og veiledning og når det gjelder hva som bidrar til profesjonell utvikling på tvers av nasjonale kontekster. 
Nøkkelord: nyutdannede lærere, induksjon, veiledning, profesjonell utvikling

\section{Introduction}

The transition from being taught to teaching others is described as a critical stage in a teacher's career (Rots et al., 2012; Fernet et al., 2016). The step from education to work is more challenging in teaching than in other professions because teachers have the full responsibility from day one (Aspfors \& Bondas, 2013). Teaching is also regarded as a particular stressful occupation (Skaalvik \& Skaalvik, 2018). Many teachers leave the profession during the first years due to challenging work conditions (Kelly et al., 2019; Tiplic et al., 2015; Perryman \& Calvert, 2020). Consequently, the first years in teaching have received a great deal of attention the last decades (Flores, 2020; Schaefer et al., 2012). Research shows there is a need for support, and mentoring has become the key strategy (Bullough, 2012). Even if there is empirical evidence for the importance of mentoring, it is still not clear what might be the best support for newly qualified teachers (NQTs) (Hobson et al., 2009; Kemmis et al. 2014; Kutsyuruba et al., 2019). However, there seems to be some commonalities involved in successful induction and mentorship across borders that makes it possible to learn across national contexts (Kutsyuruba et al., 2019). In this study we analyse narratives about the first year in teaching from NQTs in Australia, England, and Norway. Especially we wanted to know how the challenging entrance into teaching went and how the NQTs were supported. Our research questions are:

How do NQTs in different national contexts experience the entrance into teaching?

How are NQTs in different contexts supported?

The aim of the study is through examination of individual cases from cross-national contexts to learn more about new teachers needs and how to support them. In the discussion we suggest some implications of the findings.

\section{Background}

Teaching is a complex endeavour, described as "an extraordinarily difficult form of professional practice that looks easy" (Labaree, 2005, s. 188). Therefore, "Learning to teach is a process that goes beyond the mere application of a set of acquired techniques and skills" (Flores 2020, s. 146). Professional knowledge has been defined as knowledge that draws on theory (knowing that) as well as on practice (knowing how) (Clarke et al., 2013). However, to transfer knowledge from professional studies into workplace knowledge is complicated (Eraut, 2004). Generalised knowledge transmitted in higher education is not adapted to specific situations, even if it might be helpful for understanding situations (Kvernbekk, 2012). To act, practitioners always need to pay attention to situational characteristics and use their "practical wisdom" that involves sensitivity to situations and is acquired through experiences over time (Eisner, 2002). Therefore, it might be overwhelming for NQTs with limited experiences to take on the full responsibility of teachers. The challenge is how to best support them.

\section{The entrance}

The entrance into teaching, presented as a challenging and vulnerable stage in a teacher's career (Fernet et al., 2016), is described among others as a practice shock. The practice shock, a well-known concept in the literature, refers to the discrepancy between an ideal perception of teaching and the reality teachers experience in the entrance phase (Caspersen \& Raaen 2014; Johnsen et al., 2014). NQTs often end up with the most challenging classrooms and school assignments (Ingersoll \& Strong, 2011; Smith et al., 2019), something that can make a practice shock even harder. Furthermore, becoming a teacher also implies to be socialised into a school culture and a profession (Alhija \& Fresko, 2010). Some researchers describe the overwhelming start as an important learning stage in which teachers must find their own way (Caspersen \& Raaen, 2014; Fresko \& Alhija, 2009). Others report that the entrance into teaching is not merely perceived negatively. New teachers also experience mastery and believe their colleagues can learn from them (Ulvik \& Langørgen, 2012). Some of the challenges newly qualified teachers meet are personally 
related, others are depending on contextual factors connected to the workplace. Smith (2014) has grouped the challenges into four main categories. First, there are factors related to personal circumstances such as maternity, family reasons, and/or health problems. Second, there are factors related to the discrepancy newly qualified teachers may experience through the reality shock. They often start teaching with an idealistic, not always realistic understanding of what teaching contains. They may be overwhelmed by heavy workload, often caused by 'out-of-field' teaching, stealing their leisure time with family and friends. Other reasons for the disillusion are classes with too many, or difficult students. New teachers may also experience time pressure to cover the curriculum. Altogether this means not being able to be the kind of teacher they had envisioned. In some contexts, the demands of effectiveness measured in students' achievements and increasing demands for documentation at the expense of time spent with students, are likely to cause emotional stress and burnout. The third category is the characteristics of the specific school. Schools as organisations are arenas for struggle, influence, interests, and power, driven by the variety of goals, motives, and concerns of the people involved (Ball, 1994). The school may be characterised by low quality, or no mentoring, harmful collegial relations, lack of support from leadership, and colleagues who are struggling for power within the school. Anyway, the new teacher has to find a way of handling what Vanderlinde and Kelchtermans (2013) call micro-politics during their first year in the profession. When the insecurity of repeatedly being offered part-time or temporary positions are added, it is understandable that the first period of the profession is experienced as difficult. The fourth category is probably the most challenging; poor relationships with students (discipline issues), parents, colleagues and leadership of the school can strongly affect novices' emotions and experiences during the first year. A demanding entrance into teaching is reported both in Anglophone and Nordic countries, the contexts in which this study is based.

\section{The support: induction and mentoring}

To offer NQTs support during the entrance phase, the literature points to induction programmes and mentoring (Alhija \& Fresko, 2010; Colognesi et al., 2020; Morettini et al., 2020). Peer-support is suggested (Keogh et al. 2012; Le Cornu, 2013), yet, having a mentor is most important (Ingersoll \& Strong, 2011). Mentoring contributes to the feeling of acceptance and helps building NQTs resilience (Morettini et al., 2020). However, mentoring depends on the quality of mentoring (Castro et al., 2010; Hobson et al., 2009). A good relationship with the mentor is crucial (Colognesi et al., 2020), whereas a problematic relationship may produce pressure to fit into the school culture (Martin \& Rippon, 2005). Furthermore, mentoring based on standards focus on the measurable might reduce teaching to technical expertise (Fransson et al., 2018). Aiming to promote critical reflection and independent decisions, mentoring cannot be built on a hierarchical relationship (Tonna et al., 2017).

Mentoring has different purposes such as increasing teacher retention, developing effective teachers and supporting professional development (Bullough, 2012; Kemmis et al., 2014). Kemmis and colleagues (2014) found three archetypes of mentoring enabled and constrained by different local conditions and aims. The first archetype is related to guiding and supporting new teachers as they develop their professional knowledge, skills and values. The second is more instrumental, aiming to supervise new teachers as they pass through an induction phase to full registration as teachers. The third is about supporting the socialisation of teachers into the community of the profession. Mentoring practices may consist of more than one element, however, simultaneously fostering growth and acting as assessors might cause tension between support and judgement (Bullough, 2012).

\section{The study}

Despite a great deal of attention during the last decades, how to support new teachers is still discussed in the research literature. Entering the teaching profession, new teachers need support, but they also need to manage and to be recognised. While research on NQTs often is related to one national context, 
we wanted through a cross-national study, to learn more about how to balance the diverse needs during the entrance phase.

\section{Sample and context}

The study is based on narratives from three different contexts. To get a broad understanding of entrance into teaching, we chose to include a variety of cases from contexts with diverse support systems for new teachers. Narratives from Australia, Norway, and England, three countries with differences in teachers' working environments and support were selected. The sampling in the study may be characterised as convenient (Creswell, 2012). All teachers were recruited through a letter of invitation. In Norway, where we are based, we approached teachers among our teacher education's partner schools, whereas in other countries trusted colleagues approached teachers in schools they worked with in their respective countries. In Norway, twenty teachers from secondary schools responded. For the purpose of this study, we chose to concentrate on four new teachers who represented a variation in gender, subjects and kind of school. From England four teachers responded and participated and from Australia two. All the teachers were in their twenties, and the sample consisted of ten teachers from ten different schools. While the participants from England and Norway were educated in postgraduate programmes (PGCE), the Australian teachers were educated in a four-year programme for primary schools. From England and Norway there were two male and two female teachers, from Australia one of each gender. To underline that the teachers' experiences are subjective, we have given them names. The first letter in the name is the same as the the first letter in the name of the country. The great variety of the sample does not allow for a comparative analysis of the data. The interviews took place in the middle of (Norway, England) or after the first year (Australia) in teaching.

\section{Methodology}

The study used a narrative approach to understand the fullness of the NQT's experiences and to retain the complexity of the situation (Connelly \& Clandinin, 1990; Polkinghorn, 1995). The stories were collected through semi-structured interviews in which the teachers were encouraged to tell as much as possible from their first period in the profession. They were invited to explain why they chose to become teachers, to describe how their first year in teaching started, and how it subsequently developed. The participants were also asked about how they were supported and what they thought about the future. Narratives is a common form for teachers to talk about their professional experiences (Keogh et al., 2012), and during the interviews we encouraged anecdotes, images, and vignettes.

We, the researchers, developed a semi structured interview guide and conducted a joint pilot interview before dividing the Norwegian interviews between us. Thereafter the English interviews were conducted by the first author during a sabbatical at a university in England. The second author did the Australian interviews using Skype. The interviews lasted for about one hour and were recorded and transcribed. The teachers gave informed consent to participate in the study. The data were gathered over a longer period of time from 2015 to 2017. The study was planned when the first interviews were made, but due to circumstances beyond our control, the full set of data collection was prolonged.

We conducted both a narrative analysis and analysed the narratives (Polkinghorne, 1995). While narrative analysis moves from elements to stories, analyses of narratives move from stories to common elements. The narrative analysis implies to collect descriptions of events and happenings and configure them into a story. Interviews appear to be the most often used source (Polkinghorne, 1995). The outcome of the narrative analysis was ten stories developed by the researchers through a moderation process. In the process we arranged the data chronologically and decided through meaning-condensation the essence of the conversation and which elements contributed to the outcome (Kvale \& Brinkmann, 2009). Through the moderation process, we wrote the stories in first person to underline the subjective experience. To be assured that the stories fit with the data and to secure anonymity, we sent them back to the participants for member-check. In this process some minor changes were made, all related to anonymity. 
Table 1: Overview of the participants

England

\begin{tabular}{|c|c|}
\hline Elijah & $\begin{array}{l}\text { Teaches sociology and health and social care in a religious upper secondary school. Worked as } \\
\text { special needs worker before PGCE. Group meetings with a mentor every week. }\end{array}$ \\
\hline Emma & $\begin{array}{l}\text { Teaches foreign language in eight classes from year seven to ten. Works in an urban school. } \\
\text { Worked in an office before PGCE. Is mentored by the head of department. }\end{array}$ \\
\hline Ellie & $\begin{array}{l}\text { Teaches foreign languages in year seven. Is mentored by the head of the department and an } \\
\text { informal mentor. }\end{array}$ \\
\hline Evan & $\begin{array}{l}\text { Teaches Spanish in an Academy. Has a head of department role. Are not assessed by a mentor. } \\
\text { Are offered some support outside the school. }\end{array}$ \\
\hline \multicolumn{2}{|l|}{ Australia } \\
\hline Ann & $\begin{array}{l}\text { Teaches general subjects like mathematics, English and science in grade six. Is supported by } \\
\text { peers, a mentor and the school-leader. }\end{array}$ \\
\hline Anthony & $\begin{array}{l}\text { Is educated as a general classroom teacher who teaches English and Mathematics as the main } \\
\text { subjects in a primary school. Is supported by peers, mentors and the school-leader. }\end{array}$ \\
\hline \multicolumn{2}{|l|}{ Norway } \\
\hline Nils & $\begin{array}{l}\text { Teaches mathematics, physics and science in upper secondary school. Works in a rural school. } \\
\text { Limited mentoring. First educated as an engineer. The only one with a permanent position. }\end{array}$ \\
\hline Noa & $\begin{array}{l}\text { Teaches English in upper secondary school. Works as a part time, substitute teacher outside a } \\
\text { city. Has no mentor and there is limited cooperation among the teachers. }\end{array}$ \\
\hline Nina & $\begin{array}{l}\text { Teaches Norwegian in a urban upper secondary school. Has a part time position. Has no mentor. } \\
\text { Has some teaching experience before PGCE. No mentor. Limited cooperation in the school. }\end{array}$ \\
\hline Nora & $\begin{array}{l}\text { Teaches Norwegian and social science in a rural upper secondary school. Has an external } \\
\text { mentor. }\end{array}$ \\
\hline
\end{tabular}

When analysing these narratives, we followed an interpretive approach which is described as the researchers' best effort to make meaning of the data (Hatch, 2002). The narratives were read repeatedly applying a hermeneutic process which is a matter of trying to understand the whole while at the time reconsidering that whole (Gadamer, 2004/1975). The analysis of the narratives where guided by the research questions. In the process we first worked individually, then together.

\section{Findings}

The findings are presented under two main sections related to the research questions about NQTs experiences of the entrance into teaching and to how they were supported.

\section{The entrance}

Our sample consisted of teachers who seemed to manage their work and thereby likely represented positive cases. They all entered teaching because they wanted to work with people and have an impact on students' lives. The secondary school teachers also mentioned passion for their subject as a motivation. The following quotes illustrate their motivation:

I wanted to become a teacher because I love languages and wanted to share my love of languages with other people. (Emma, England). 
I love the interaction with the kids. I really enjoy working with pupils and see them develop [...] I hope I could have had a bit of influence on their lives (Anthony, Australia).

Most interviewees were inspired by other teachers in their career choice, either their own teachers or teachers in their family. Nina from Norway explained: "Deep down I have always wanted to become a teacher. My parents are also teachers." Becoming a teacher was a deliberate choice, and most of the participants had some positive role models and some ideas about what kind of teachers they wanted to be.

It was not easy for the NQTs to get a job. They had to apply for positions in competition with many other applicants, and it gave them self-confidence to be chosen. One of the English teachers, Elijah, explained: "I had my second placement in this school. I really enjoyed the school and think they quite liked me as well". Some of the Norwegian teachers were less successful in getting a full-time job. Noa described:

The $25 \%$ was all I got initially. I applied for a lot of jobs, also in lower secondary [...] After only a couple of days, I had a $40 \%$ job, and later $80 \%$. I do not know, however, if I will have a job for the next school year.

The English teachers had to pass their probationer year, whilst other teachers had to apply for a new position the next year. Having a temporary position could be stressful because the teachers then had to convince the school that they deserved the job.

Despite initial motivation for teaching, the start was characterised as busy with a heavy workload in all three contexts. It was a common understanding that the job was tougher than expected with responsibilities the NQTs were not prepared for. In England and Norway there were examples of out of field teaching, and the Australian teachers had to handle students with special needs like autism and Asperger's Syndrome. They were exposed to tasks even experienced teachers find challenging. Furthermore, it was difficult to get an overview over the work like Anthony from Australia experienced: "I was not fully aware of what the job entailed, and I did not understand how much work I should put into it".

What is mentioned above seems to support a discrepancy between the ideal and reality in all countries. Despite various support systems, they all felt thrown into teaching without having an overview of their work. Nora from Norway explained: "I got some information about the students, and then: good luck and remember the parents meeting on Thursday". On the positive side they all encountered friendly colleagues and had confidence in their own content knowledge and teaching skills.

The abrupt entrance into teaching raised a range of emotions, and the NQTs used a lot of value-loaded words when talking about their experiences. The interviews were full of positive statements as illustrated below:

I just love the spontaneity of my profession [...]. What will happen today? And I also enjoy the freedom of it (Anthony, Australia).

I am so glad for all my experience when it comes to natural sciences. It makes me so confident in my subjects and then I can concentrate on other issues (Nils, Norway).

However, even after a short period of teaching, it was possible to see a change like Nora from Norway exemplified: "It's the head above the water and surviving from lesson to lesson feeling without drowning I have now. But I've started to master". The new teachers' emotions were especially related to students. They wanted a good relationship and felt miserable when there were problems. All critical incidents were related to students. Overcoming challenges, especially related to critical incidents with students, strengthened the resilience and the perception of competence. Furthermore, being with students was the best part of the job. Emma explained: "For example when I see my students in the corridor and they say, 'bonjour' or 'hola', I think that is nice, that is warming".

NQTs even problematised how experienced teachers handled students. "Just because someone has been teaching for fifteen years and they tell me what I should do, I don't always have to follow it if I don't believe in it', Anthony claims.

Sometimes the new teachers succeeded with their work and became even more self-confident. Ann from Australia stated: "I think I'm also impressed with myself and the amount of stuff that I have learned 
throughout the past year". The positive emotions had conquered the negative ones. Furthermore, the teachers were individuals with their different preferences. While Elijah enjoyed planning lessons, Evan described planning as the hardest bit. He became head of a department and enjoyed the responsibility that he would not have had in another school. Others could have been terrified. Nina on her side, deliberately chose to work in a part time position in what she perceived as a good school in order to get a positive start on her career. Nils explained that he had never been afraid of asking questions. All the NQTs showed a kind of resilience.

\section{The support: induction and mentoring}

Induction and mentoring represented the greatest differences in the data. The context and the formal system differed, but there were also examples showing that induction and mentoring depended on the involved people as claimed by Bullough (2012). The two Australian teachers who were very well supported seemed less overwhelmed by their workload. Anthony explained that he had a mentor with five years' experience whom he could ask all kinds of questions. He was also in team with three experienced teachers. They had weekly meetings in which they planned their teaching together. Furthermore, there were five new teachers in the school. They had regular meetings with the assistant principal and became friends. Ann experienced a similar support from different persons who might complement each other. The Australian teachers were thereby supported to enter the professional community (Kemmis et al., 2014). The assessment dimension seemed limited. However, even if the mentoring system worked well for these teachers, it could not compensate for worries about the next job. Ann said that she had to reapply for her job and that only three of five new teachers in her school would have a job there the next year. However, the Australian teachers explained that friends from the University had not been that lucky with the staff and the support in their schools.

In Norway, the new teachers had to carry the full responsibility as teachers and to cope with the job on their own. They were thrown in at the deep end, but at the same time they were free to do as they wanted. Even if all new teachers in Norway are supposed to be mentored, the support appears as limited. Norwegian teachers are certified for the rest of their career when they enter the profession. It seems that without support, or time for reflection the NQTs might find it easy to fall into routines of teaching. The heavy workload made it difficult to take risks and it was easier to stick to what they knew beforehand. Left on their own they missed feed-back on their teaching. Most colleagues were helpful when they were asked, but Noa and Nina both criticised their colleagues' lack of willingness to collaborate. Nina stated that there were a lot of men in her school that "knew" how to teach, and she added: "Therefore there is not much cooperation, as I see it. There is a lot of sharing, but very little acceptance". She experienced that her colleagues did not expect to learn something from her. Nils from Norway was the only new teacher in our sample with a permanent job. The school needed his competence. When he realised that he was expected to teach a class with disabled students, he was in a position to tell his leader that he was not ready for the challenge, and his job was changed.

In England, all the teachers had a mentor. However, the support they got was quite different and varied from meetings every week to almost no support. Elijah, the one with the most extensive support, and the only one who worked in a top-level school, was also most positive towards being assessed. He mentioned friends who worked in Academies (independent state funded schools) where the leaders could do as they like and where they put a lot of pressure on the staff. Evan who worked in an Academy appreciated to get responsibility and by that felt recognised. Ellie had a formal as well as an informal mentor closer to her age. The school had chosen a shared mentor role. The informal mentor was there only for support and for helping her into the professional community. The formal mentor was the head of department. She found it very useful to have an appointed mentor with just a few more years of experience than herself who was not supposed to assess her.

The English teachers seemed to be part of a system into which they had to adapt. They were supported, but also "overlooked" as one of them explained. In other words, they were supervised on their way to full registration (Kemmis et al., 2014). However, they tended to accept the working conditions: "To 
be observed is partly good for the feedback and partly it keeps you on your toes. You have to keep your lessons fresh and to try new ideas" (Elijah). As we understand from the quote, mentoring and assessment could be helpful, but could also be understood as a threat. The English teachers had to fulfil explicit standards related to teaching skills, but to know what was expected might make them feel secure. They seemed to have a clear understanding of what they were supposed to do. However, even if there was a formal mentoring system in England, practice depended on the mentor. Emma explained:

During the year we are observed by the mentor. I've had one visit already, but l've not got any feedback. Another colleague told me that the mentor should have given me feedback straight away. Anyhow, we've got eight standards in England and the mentors just tick them or not. I've to meet the standards to keep my job.

She was inspected and assessed by the head of the department, but the supporting dimension of mentoring was lacking. Elijah on his side was aware of the high demands, however he felt supported. His mentor, who was not in a leader position, was able to balance support and assessment.

The teachers in our study seemed to manage stress. They all wanted to continue in the profession and believed that next year would be better as they would be more experienced, more familiar with the system and consequently more efficient. Even if the workload had been heavier than expected, the positive experiences seemed to overshadow the negative ones.

\section{Discussion}

The findings support commonalities across contexts and confirm entrance as a critical stage in teachers' careers (Kutsyuruba et al., 2019). Starting to teach was overwhelming for all the teachers and implied processing of experiences and emotions and a pressure to make a good impression. There was a need for workplace learning and support that depended on time, cooperation, and mentoring. However, the findings also revealed what factors made teachers succeed, and differences among contexts and individuals, especially related to induction and mentoring.

\section{The entrance}

The teachers in the study started with high ambitions especially concerning their subjects and working with people. Teaching seems to be more than just a job, and the motivation can be characterised as intrinsic and altruistic (Watt \& Richardson, 2007). However, despite different contexts, cultures, teacher education programmes, backgrounds, individual preferences, and support for new teachers, even the apparently successful and motivated teachers in our study had a hard time when entering the profession (Alhija \& Fresko, 2010; Fernet et al., 2016). They found the job busier than expected, and it was a challenge to live up to their own ideals. Teaching was about dealing with specific situations that was beyond the technical or cognitive. It involved emotions and presupposed an ongoing dialogue related to practice (Aspfors \& Bondas, 2013; Flores, 2020; Squires, 2019). They realised how much workplace learning took place and the value of having a mentor they could trust. Limited time and access to cooperation with colleagues and mentors might hinder their learning to teach.

The teachers pointed at busyness related to doing things for the first time, unexpected assignments, and a pressure to make a good impression as crucial challenges. Being thrown into teaching implied a lot of feelings that needed processing. Emotions are a built-in part of teaching and should be addressed in learning and development activities (Jakhelln, 2010). Especially for new teachers it is crucial that negative experiences do not dominate and that they feel accepted (Morgan et al., 2010; Morettini et al., 2020). However, to reveal negative emotions in a situation where teachers want to keep their job or are afraid of being assessed is not easy. Overwhelmed by the job it is easy for new teachers to teach as they have been taught (Lunenberg et al., 2007; Smith et al., 2019) - and not make use of the engagement and ideas they bring into schools.

Despite challenges, the positive emotions were dominant for the participants. Thereby, naming the entrance phase as a practice shock seems to be too strong in most cases. Even if the job was busier than 
expected, the new teachers also enjoyed their job and were optimistic about the future. The challenges were especially related to two of the four aforementioned categories (Smith, 2014): discrepancy between an idealistic and realistic understanding of teaching as well as characteristics of the organisation, like no or limited mentoring or temporary positions. Personal circumstances and poor relationships seem not to be an issue.

What contribute to success seem to be the NQTs intrinsic motivation, mastery experiences, content knowledge, the positive relationship to students and to meet friendly colleagues.

\section{The support: induction and mentoring}

The entrance phase is characterised by heavy workload, and full responsibility as teachers from day one in all contexts. Learning at the workplace was arranged for some, for others not. Even if there were national arrangements, like in England, the local schools had their unique versions of it. Furthermore, the support depended on the mentor, concerning the time the mentor had for the job, the position the mentor was in (like head of the department) as well as how the mentors understood their responsibility (assessing, supporting, collaborating). It can add to NQTs stress to be mentored by a leader (Colognesi et al., 2020). Here an informal mentor, like the one Ellie from England got, or a group of new teachers supporting each other, like in Australia, seem useful. Support also depended on the school culture and how the teachers cooperated. However, the support resources available and the understanding of induction differed, and we find traces of all the different archetypes of mentoring presented by Kemmis et al. (2014). Some NQTs were supported, other supervised, and some, like Elijah, experienced supervision and support from the same mentor. Furthermore, some got access to resources in the professional community in various ways. Anthony, Ann and Elijah were all included in a group with other new teachers, and Anthony and Ann were also part of a group with experienced teachers. The Norwegian teachers got access to other teachers experiences if they asked for it, but the interaction seemed to be one-sided. Lacking access to cooperating communities with multiple interpretations and analyses might negatively impact new teachers' learning (Flores, 2020).

While the most common pressure on NQTs relates to workload, students' behaviour and leadership (Gu \& Day, 2007) the interviewees did not emphasise problems with students or leadership. Still, they experienced challenges related to their position as newcomers. What made it difficult to fulfil their goals was the busyness and lack of overview, also known from the literature (Johnsen et al., 2014). Reduced teaching hours, mentoring and cooperating with a team of teachers and learning from other teachers' experiences might lessen the pressure (Le Cornu, 2013; Mansfield \& Gu, 2019). Especially the Australian teachers had positive experiences with a varied support system that made the induction less uniformed and thereby more flexible for different needs. Their experiences are supported by Bullough (2012) who states that effective induction requires more than one mentor can provide. Various kinds of supports are needed, including emotional support (Bullough, 2012; Colognesi et al., 2020; Squires, 2019).

What role does assessment play in an induction programme? In England especially three of the NQTs were inspected to see if they met the Teachers' Standards (Department of Education, 2013). They seem to be subject to what can be characterised as a training model of teaching (Harrison et al., 2006). However, we learned that the training centred approach with fixed standards can be practiced in ways that are supportive and perceived as helpful, like in Elijah's case. Being observed and getting supportive feedback from a mentor who was not in a leader position made him feel confident. Leaving NQTs to themselves, as in Norway, can sometimes leave NQTs to re-invent the wheel.

To have an appointed mentor was appreciated in all contexts when it came to support and feedback. The new teachers found their colleagues friendly, but not all of them had time for collaboration or saw it as their responsibility to support new members of the profession. Teachers are busy and it is not always easy to ask colleagues about everything a newcomer needs to know. However, the mentor's personality and the quality of mentoring seem crucial (Colognesi et al., 2020; Hobson \& Maxwell, 2020). Emma and Elijah were both part of the same national context, but the quality of the mentoring was different. However, mentoring is also influenced by external factors like recognition of mentors and support 
structures (Hobson \& Maxwell, 2020). Mentoring is different from teaching (Bullough, 2012), and quality mentoring may depend on education beyond qualification for teachers (Aspfors \& Fransson 2015). Mentor education seems to contribute to develop mentors' analytic skills and enhance their reflection and their ability to talk about and discuss teaching (Helleve \& Ulvik, 2019; Ulvik \& Sunde, 2013). However, mentoring is not just an individual endeavour. It needs to be integrated into the school culture (Aspfors \& Fransson, 2015). Moreover, why should support be reserved only for new teachers? A more collaborative approach might avoid an individualistic approach to professionalism and promote more collaborative self-development (Kemmis et al., 2014). Without dialogue it is easy to resign to the way things are. A system is likely to be challenged every time a new participant enters it, consequently both new and experienced teachers could gain from cooperation.

The NQTs' updated professional knowledge and skills did not seem to be fully exploited by the schools in our study. New teachers bring resources into a workplace that should be recognised (Ulvik \& Langørgen, 2012). Recognition implies being listened to as well as being subject to expectations and being challenged, an encouragement that might strengthen teachers' resilience, but also contribute to professional development in the workplace.

\section{Limitations}

This is a small-scale study and the examples from each country cannot to be perceived as representative. Furthermore, there is a limitation linked to the fact that the researchers are Norwegians, something that might influence the interviews as well as the analyses. Another limitation is the timespan over which data were collected. With these limitations in mind, we will finally sum up what we learned from the study.

\section{Implications}

Based on our study we suggest that both being left alone, like the Norwegian teachers were, or "overlooked", as the English teachers experienced, may contribute to adapt to traditional teaching. Teachers who are left alone may neither get the necessary time to acquaint themselves with their profession, nor get support and encouragement to use their own potential resources in teaching. Teachers who primarily are supervised to meet explicit standards are in danger of adopting current school practice, and their new ideas might be disregarded. In both cases, school development suffers from not including the newcomers' perspectives. What seems to be helpful is to be mentored in a supportive way with less attention to the assessment part, as the Australian teachers experienced. Balancing support and assessment is challenging, and is a process that needs time (Bullough, 2012).

The new teachers wanted to have an impact. They were strengthened by mastery experiences and positive relationships (Le Cornu, 2013; Mansfield \& Gu, 2019). Then it is not sufficient to be supported and perceived as helpless. The new teachers are prepared for difficulties and overcoming challenges may increase their self-efficacy and resilience. The Australian teachers who managed students with special needs are examples here. Nevertheless, the workload should be manageable so that at the end of the year the new teachers still possess courage and motivation to continue in teaching - not only by accident.

Based on our study we suggest that mentoring should be a part of induction programmes, simultaneously knowing that one mentor is not enough. New teachers should be given time and opportunities for processing emotions and experiences and learn from their practice in cooperation with others. Having access to different perspectives might help teachers develop their own perspective without feeling a pressure to adapt. It is not enough to address the structure of induction and mentoring. The content and quality also should be considered, and mentoring should adapt to individual needs and not be judgemental (Squires, 2019). Offering a dynamic support system might be a solution to meet this challenge. 


\section{Concluding comments}

New teachers with different backgrounds and from a diversity of contexts experienced all the entrance into teaching as overwhelming. What we learned from the narratives is that there regardless of contexts is a need for support in the shape of workplace learning that includes necessary time, manageable workload, cooperation with colleagues and an appointed and competent mentor. Furthermore, while the research literature underlines the need for support, we want to emphasise that new teachers also need to be part of a community where they can contribute. If the aim is to teach as one has been taught and focus on certain skills, then NQTs are likely to copy experienced teachers. If the aim is to develop teaching in a changing society, it is harder to define good teaching and there is no right way of teaching. We recommend that all teachers, new and experienced, need to engage in professional dialogues and develop the profession together. For this to happen we see quality mentoring as crucial.

\section{References}

Alhija, F. N-A. \& Fresko, B. (2010). Socialization of new teachers. Does induction matter? Teaching and Teacher Education, 26, 1592-1597. https://doi.org/10.1016/j.tate.2010.06.010

Aspfors, J. \& Bondas, T. (2013). Caring about caring. Newly qualified teachers' experiences of their relationships within the school community. Teachers and Teaching, 19(3), 243-259. https://doi.org/10.1080/13540602.2012.754158

Aspfors, J. \& Fransson, G. (2015). Research on mentor education for mentors of newly qualified teachers. A qualitative meta-synthesis. Teaching and Teacher Education, 48, 75-86. https://doi.org/10.1016/j.tate.2015.02.004

Ball, S. (1994). Education Reform. A critical and post-structural approach. Open University Press.

Bullough Jr, R. V. (2012). Mentoring and new teacher induction in the United States. A review and analysis of current practices. Mentoring \& tutoring: partnership in learning, 20(1), 57-74. https://doi.org/10.1080/13611267.2012.645600

Caspersen, J., \& Raaen, F.D. (2014). Novice teachers and how they cope. Teachers and Teaching, 20(2), 189-211. https://doi.org/10.1080/13540602.2013.848570

Castro, A. J. Kelly, J. \& Shih, M. (2010). Resilience strategies for new teachers in high-needs areas. Teaching and Teacher Education, 26, 622-629. https://doi.org/10.1016/j.tate.2009.09.010

Clarke, M., Killeavy, M. \& Moloney, A. (2013). The genesis of mentors' professional and personal knowledge about teaching: perspectives from the Republic of Ireland. European Journal of Teacher Education, 36(3), 365-375. https://doi.org/10.1080/02619768.2012.755513

Colognesi, S., Van Nieuwenhoven, C. \& Beausaert, S. (2020). Supporting newly-qualified teachers' professional development and perseverance in secondary education. On the role of informal learning. European Journal of Teacher Education, 43(2), 258-276, https://doi.org/10.1080/02619768.2019.1681963

Connelly, F. \& Clandinin, D. (1990). Stories of experience and narrative inquiry. Educational Researcher, 19(5), 2-14. https://doi.org/10.3102/0013189X019005002

Creswell, J.W. (2012). Educational research. planning, conducting, and Ninaluating quantitative and qualitative research. Pearson.

Department of Education (2013). Teachers' Standards. Guidance for School Leaders, School Staff and Governing Bodies. Accessed 01 February 2021. www.gov.uk/government/publications

Eisner, E. (2002). From episteme to phronesis to artistry in the study and improvement of teaching. Teaching and Teacher Education, 18, 375-385. https://doi.org/10.1016/S0742-051X(02)00004-5

Eraut, M. (2004). Informal learning in the workplace. Studies in Continuing Education, 26(2), 247-273. https://doi.org/10.1080/158037042000225245 
Fernet, C., Trépanier, S-G., Austin, S \& Levesque-Côté, J. (2016). Committed, inspiring, and healthy teachers. How do school environment and motivational factors facilitate optimal functioning at career start? Teaching and Teacher Education, 59, 481-491. https://doi.org/10.1016/j.tate.2016.07.019

Flores M. A. (2020). Feeling like a student but thinking like a teacher. A study of the development of professional identity in initial teacher education. Journal of Education for Teaching, 46(2), 145-158. https://doi.org/10.1080/02607476.2020.1724659

Fransson, G., Gallant, A. \& Shanks, R. (2018). Human elements and the pragmatic approach in the Australian, Scottish and Swedish standards for newly qualified teachers. J Educ Change 19, 243-267. https://doi.org/10.1007/s10833-018-9321-8

Fresko, B. \& Alhija, F. N-A. (2009). When intentions and reality clash: Inherent implementation difficulties of an induction program for new teachers. Teaching and Teacher Education, 25(2), 278284. https://doi.org/10.1016/j.tate.2008.12.001

Gadamer, H-G. (2004/1975). Truth and method. Continuum.

Gu, Q. \& Day, C. (2007). Teachers resilience. A necessary condition for effectiveness. Teaching and Teacher Education, 23, 1302-1316. https://doi.org/10.1016/j.tate.2006.06.006

Harrison, J., Dymoke, S. \& Pell, T. (2006). Mentoring beginning teachers in secondary schools: An analysis of practice. Teaching and Teacher Education, 22, 1055-1067. https://doi.org/10.1016/j.tate.2006.04.021

Hatch, A. (2002). Doing qualitative research in education settings. State University of New York Press.

Helleve, I. \& Ulvik, M. (2019). Tutors seen through the eyes of mentors assumptions for participation in third space in teacher education. European Journal of Teacher Education, 42(2), 228-242. https://doi.org/10.1080/02619768.2019.1570495

Hobson, A. J. \& Maxwell, B. (2020). Mentoring substructures and superstructures: an extension and reconceptualization of the architecture for teacher mentoring. Journal of Education for Teaching, 46(2), 184-206. https://doi.org/10.1080/02607476.2020.1724653

Hobson, A.J., Ashby, P., Malderez, A., Tomlinson, P.D. (2009). Mentoring beginning teachers: What we know and what we don't. Teaching and Teacher Education, 25(1), 207-216. https://doi.org/10.1016/j.tate.2008.09.001

Ingersoll, R.M. \& Strong, M. (2011). The impact of induction and mentoring programs for beginning teachers. A critical review of the research. Review of Educational Research, 81(2), 201-233. https://doi.org/10.3102/0034654311403323

Jakhelln, R. (2010). Early career teachers' emotional experiences and development. A Norwegian case study. Professional Development in Education, 37(2), 275-290. https://doi.org/10.1080/19415257.2010.517399

Johnsen, B., Down, B. Le Cornu, R. Peters, J. Sullivan, A. Pearce, J. \& Hunter, J. (2014). Promoting early career teacher resilience: a framework for understanding and acting. Teachers and Teaching, 20(5), 530-546. https://doi.org/10.1080/13540602.2014.937957

Kelly, N., Cespedes, M., Clara, M. \& Danaher, P. (2019). Early career teachers' intentions to leave the profession. The complex relationships among preservice education, early career support, and job satisfaction. Australian Journal of Teacher Education,44(3), 93-113. https://ro.ecu.edu.au/ajte/vol44/iss3/6/

Kemmis, S., Heikkinen, H.L.T., Fransson, G., Aspfors, J. \& Edwards-Groves, C. (2014). Mentoring of new teachers as a contested practice. Supervision, support and collaborative self-development. Teaching and Teacher education, 43, 154-164. https://doi.org/10.1016/j.tate.2014.07.001 
Keogh, J., Garvis, S., Pendergast, D. \& Diamond, P. (2012). Self-determination. Using Agency, Efficacy and Resilience (AER) to counter novice teachers' experiences of intensification. Australian Journal of Teacher Education, 37(8), 46-65. http://ro.ecu.edu.au/ajte/vol37/iss8/4

Kutsyuruba, B., Walker, K. D., \& Godden, L. (2019). Contextual factors in early career teaching: A systematic review of international research on teacher induction and mentoring programs. Journal of Global Education and Research, 3(2), 85-123. https://www.doi.org/10.5038/2577-509X.3.2.1057

Kvale, S., \& Brinkmann, S. (2009). Interviews. Learning the craft of qualitative research interviewing (2nd ed.). Sage Publications.

Kvernbekk, T. (2012). Argumentation in theory and practice. Gap or equilibrium? Informal Logic, 32(3), 288-305. https://doi.org/10.22329/il.v32i3.3534

Labaree, D. F. (2005). Life on the margins. Journal of Teacher Education, 56(3), 186-191.

Le Cornu, R. (2009). Building resilience in pre-service teachers. Teaching and Teacher Education, 25(5), 717-723. https://doi.org/10.1016/j.tate.2008.11.016

Lunenberg, M., Korthagen, F., \& Swennen, A. (2007). The teacher educator as a role model. Teaching and Teacher Education, 23, 586-601. https://doi.org/10.1016/j.tate.2006.11.001

Mansfield, C., Gu, Q. (2019). “I'm finally getting that help that I needed”. Early career teacher induction and professional learning. Aust. Educ. Res. 46, 639-659. https://doi.org/10.1007/s13384-01900338-y

Martin, M., \& Rippon, J. (2005). Everything is fine. The experience of teacher induction. Journal of Inservice Education, 31(3), 527-544. https://doi.org/10.1080/13674580500200292

Morettini, B., Luet, K. \& Vernon-Dotson, L. (2020) Building beginning teacher resilience. Exploring the relationship between mentoring and contextual acceptance. The Educational Forum, 84(1), 48-62. https://doi.org/10.1080/00131725.2020.1679933

Morgan, M., Ludlow, L., Kitching, K., O'Leary, M. \& Clarke A. (2010). What makes teachers tick? Sustaining events in new teachers' lives. British Educational Research Journal, 36(2),191-208. https://doi.org/10.1080/01411920902780972

Perryman, J. \& Calvert, G. (2020). What motivates people to teach, and why do they leave? Accountability, performativity and teacher retention. British Journal of Educational Studies, 68(1), 3 23. https://doi.org/10.1080/00071005.2019.1589417

Polkinghorne, D.E. (1995). Narrative configuration in qualitative analysis. International Journal of Qualitative Studies in Education, 8(1), 5-23. https://doi.org/10.1080/0951839950080103

Rots, I., Kelchtermans, G. \& Aelterman, A. (2012). Learning (not) to become a teacher. A qualitative analysis of the job entrance issue. Teaching and Teacher Education, 28, 1-10. https://doi.org/10.1016/j.tate.2011.08.008

Schaefer, L., Long, J. S. \& Clandinin. D. J. (2012). Questioning the research on early career teacher attrition and retention. Alberta Journal of Educational Research, 58(1), 106-121.

Skaalvik, E. M. \& Skaalvik, S. (2018). Job demands and job resources as predictors of teacher motivation and well-being. Social Psychology of Education, 21, 1251-1275. https://doi.org/10.1007/s11218-0189464-8

Smith, K. (2014, February). One a teacher, always a teacher? Examining teacher attrition in a Norwegian and international perspective (Application submitted to the Norwegian research council, FINNUT program). Bergen: University of Bergen.

Smith, K., Ulvik, M. \& Helleve, I. (2013). Førstereisen. Lærdom hentet fra nye læreres fortellinger. Gyldendal Akademisk.

Smith, K., Ulvik, M. \& Helleve, I. (2019). Lessons learned from Novice Teachers. Brill/Sense. 
Squires, V. (2019). The well-being of the early career teacher. A review of the literature on the pivotal role of mentoring. International Journal of Mentoring and Coaching in Education, 8(4), 255-267. https://doi.org/10.1108/IJMCE-02-2019-0025

Tiplic, D., Brandmo, C., \& Elstad, E. (2015). Antecedents of Norwegian beginning teachers' turnover intentions. Cambridge journal of education, 1-24. https://doi.org/10.1080/0305764X.2014.987642

Tonna, M. A., Bjerkholt, E. \& Holland, E. (2017). Teacher mentoring and the reflective practitioner approach. International Journal of Mentoring and Coaching in Education, 6(3), 210-227. https://doi.org/10.1108/IJMCE-04-2017-0032

Ulvik, M. \& Langørgen, K. (2012). What is there to learn from a new teacher? Newly qualified teachers as a resource in schools. Teachers and Teaching, 18(1), 43-57. https://doi.org/10.1080/13540602.2011.622553

Ulvik, M. \& Sunde, E. (2013). The impact of mentor education: does mentor education matter? Professional Development in Education, 39(5), 754-770. https://doi.org/10.1080/19415257.2012.754783

Vanderlinde, R. \& Kelchtermans G. (2013). Learning to get along at work: Micropolitical learning in teachers' first year. Phi Delta Kappan, 94, 33 - 37 https://doi.org/10.1177/003172171309400713

Watt, H. M., \& Richardson, P. W. (2007). Motivational factors influencing teaching as a career choice. Development and validation of the FIT-choice Scale. The Journal of Experimental Education, 75(3), 167-202. https://doi.org/10.3200/JEXE.75.3.167-202 